\title{
Negative Pressure Pulmonary Edema After Orthognathic Surgery
}

\author{
Ortognatik Cerrahi Sonrası Negatif Basınçlı Pulmoner Ödem Gelişimi
}

\author{
Seçil ÇUBUK (D), Zeliha Aycan ÖZDEMIRKAN (D), Burak BAYRAM (D)
}

\begin{abstract}
Negative-pressure pulmonary edema can arise in patients having upper airway obstruction following extubation. This report aims to present the case that had negative-pressure pulmonary edema after orthognathic surgery and to review the literature. Twenty-sevenyear-old male patient underwent bimaxillary orthognathic surgery. At the postanesthesia care unit, the patient had marked respiratory distress and significant arterial oxygen desaturation. The patient was reintubated and transported to the Intensive Care Unit. Extubation was done after 6 hours and continuous positive airway pressure was applied for 2 days at the Intensive Care Unit. On the postoperative second and third day, vascular congestion resolved on the chest radiograpies. C-reactive protein, leukocyte, neutrophil counts, partial pressure of the arterial oxygen and carbon dioxide showed improvement during the treatment. Negative-pressure pulmonary edema is a life-threatening complication that can be seen after orthognathic surgery and can be managed with early diagnosis and accurate treatment protocol.
\end{abstract}

Keywords: Pulmonary Edema; Orthognathic Surgery; Oral Surgeries; General Anesthesia

Seçil ÇUBUK (ब)

Assistant Professor; Baskent University,School of Dentistry, Department of Oral and Maxillofacial Surgery, Ankara, Turkey

e-mail: secilcubuk@hotmail.com

Zeliha Aycan ÖZDEMIRKAN

Assistant Professor; Gazi University, School of Medicine, Anesthesiology and Reanimation

Burak BAYRAM

Professor; Baskent University, School of Dentistry, Department of Oral and Maxillofacial Surgery, Ankara, Turkey

This study was presented as "Oral Presentation" and published on the IJOMS abstract supplement for International Conference on Oral and Maxillofacial Surgery held on May 21-24, 2019 in Rio de Janeiro, Brazil.

Submitted / Gönderilme: 20.10.2019 Accepted / Kabul:30.06.2020
Öz

Negatif basınçlı pulmoner ödem (NBPÖ) şiddetli negatif intratorasik basınç oluşturan spontan solunum eforu ve üst solunum yolu obstrüksiyonu bulunan hastalarda oluşmaktadır. Bu vaka raporu ve derlemenin amacı çift çene ortognatik cerrahi ameliyatı sonrasında NBPÖ gelişen bir vakanın takdimi ve bu konuyla ilgili literatür derlemesidir.

27 yaşında erkek hastaya çift çene ortognatik cerrahi ameliyatı uyguland. Postanestezik bakım ünitesinde hastada belirgin bir solunum sıkıntısı ve arterial oksijen desaturasyonu gelişti. Hasta yeniden entube edilip invaziv mekanik ventilasyon ve takip için yoğun bakım ünitesine nakledildi. 48 saat sonra hasta yoğun bakım ünitesinden yatakl1 servise nakledildi. Postoperatif 2 . gün ve 3. gün göğüs radyografilerinde vaskuler konjesyonda iyileşme görüldü. Yoğun bakım ünitesinde tedavi sürecinde C-reaktif protein, lökosit ve nötrofil değerleri normal seviyelerine döndü. Arteryal kan gazı analizinde parsiyel arteryal oksijen ve karbondioksit basincında iyileşme olduğu belirlendi. Hasta postoperatif 4. günde taburcu oldu.

Negatif basınçlı pulmoner ödem ortognatik cerrahi sonrasında görülebilen hayati tehdit oluşturan bir tablodur. Postanestezik bakım ünitesinde hastanın dikkatli takibi, klinisyenlerin hastalığın klinik özellikleri hakkında yeterli bilgiye sahip olması ve tedavisinde deneyim sahibi olması NBPÖ'in başarıyla tedavisinde önemli rol oynayan hususlardır.

Anahtar kelimeler: Pulmoner Ödem; Ortognatik cerrahi; Oral Cerrahiler; Genel Anestezi

\section{Introduction}

Negative-pressure pulmonary edema (NPPE) arises in patients having upper airway obstruction along with spontaneous respiratory effort, which generates extremely negative intrathoracic pressures. The overall incidence of NPPE is reported less than $0.1 \%$ in all surgeries performed under general anesthesia [1].

The pathogenesis of NPPE is highly complex. Inspiration against an obstructed upper airway and forceful diaphragmatic efforts cause high levels of negative pleural 
pressure which raise the venous return to the right side of the heart. This may generate higher hydrostatic pressures in the pulmonary capillaries; induce alveolar flooding and pulmonary edema. This pathologic condition results in sudden respiratory system dysfunction and a decrease in $\mathrm{O} 2$ saturation [2].

There are several etiological factors other than post-extubation laryngospasms, such as upper airway tumors, obstructive sleep apnea, foreign bodies, hanging, strangulation, vocal cord palsy, and difficult intubation [3]. The most common risk factors for NPPE are reported as young age, male sex, and head and neck surgery [4].

There are very limited case reports which present NPPE associated with dental procedures and orofacial surgery in the literature [3,5-10]. This report aims to present the case that had NPPE after bimaxillary orthognathic surgeries and to review the reported data related to NPPE after oral procedures.

\section{Case Report}

Twenty-seven-year-old male patient referred to Başkent University Department of Orthodontics with a complaint of lower jaw prognathism. Bimaxillary surgeries were planned as he had also maxillary retrusion. Preoperative orthodontic treatment was completed in 9 months.

He had an only seasonal allergy as a systemic disease and used antihistaminic when allergic symptoms occurred. He had no other systemic diseases or drug usage. He was $169 \mathrm{~cm}$ tall and weighed $68 \mathrm{~kg}$. The values at the complete blood count tests were in the normal ranges. The intubation difficulty was determined as Mallampati 2 at the preoperative examination.

The patient was transferred to the operating room for the planned surgical intervention. Anesthesia induction was done using fentanyl $50 \mathrm{mcg}$, propofol $200 \mathrm{mg}$, and esmeron $50 \mathrm{mg}$ and it was maintained with $\mathrm{O}_{2}$ and isoflurane.

The maxilla moved $5 \mathrm{~mm}$ forward using Le Fort 1 osteotomy and the mandible moved $4 \mathrm{~mm}$ backward using bilateral sagittal split osteotomy. (Fig 1) The planned surgical procedures were completed uneventfully within four hours and twenty-five minutes. The total blood loss amount was established as $890 \mathrm{mg}$. The fluid replacement was performed with $3500 \mathrm{ml}$ physiologic multielectrolyte solution (Isolyte, Eczacıbaşı-Baxter, Turkey). He was responsive to verbal command, on adequate spontaneous ventilation, and was extubated with the standard procedures and transferred to the postanesthesia care unit (PACU). At the PACU the patient became unconscious, developed marked respiratory distress and significant arterial oxygen desaturation (65\%). The patient was reintubated and $\mathrm{O}_{2}$ supplementation was provided using a bag valve attachment to the endotracheal tube since paradoxical respiration did not improve despite the aid of mask ventilation. Discharge of foamy fluid from the oral cavity was observed, therefore initial diagnosis was considered as acute pulmonary edema. The patient was transported to the Intensive Care Unit (ICU) for invasive mechanical ventilation and follow-up.

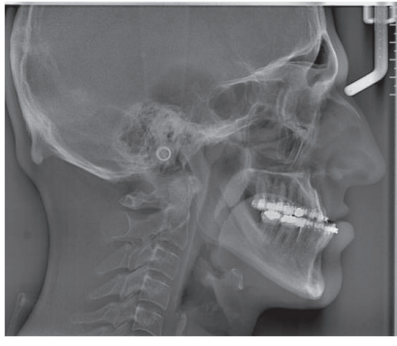

Fig 1.

A: Preoperative cephalometric radiography of the patient.

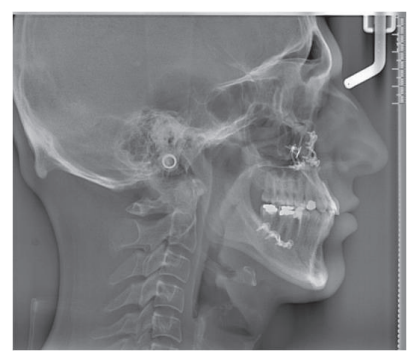

B: Postoperative cephalometric radiography of the patient.
The patient was maintained with the hemodynamic stability in the ICU. Chest radiography showed pulmonary vascular congestion. (Fig 2-A) Twenty mg furosemide and $120 \mathrm{mg}$ metilprednizolon were administered intravenously on the first postoperative day. Sixty mg metilprednizolan was given after 6 hours from the first administration. Extubation was made after 6 hours of invasive positive pressure ventilation and $\mathrm{O}_{2}$ supplemantation was provided by nasal cannula. Additionally, noninvasive ventilation with oronasal facemask was applied for 15 minutes per hour on the first postoperative day. On the second day, its frequency was decreased to 15 minutes per 2 hours.

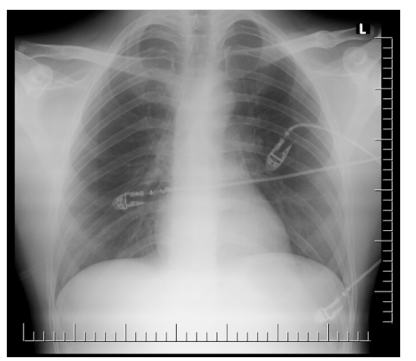

Fig 2.

A: Pleural effusion appears on the chest radiography on the $1^{\text {st }}$ postoperative day.

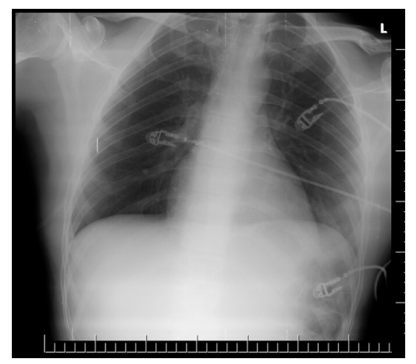

B: Slight pleural effusion was seen on the $3 \mathrm{rd}$ postoperative day. 
CRP, leukocyte and neutrophil counts improved during the treatment at ICU (Fig 3). Arterial blood gas analysis revealed that the partial pressure of arterial oxygen and carbon dioxide showed improvement during the therapy (Table 1). The patient was transferred to the general ward from ICU on the second postoperative day. Vascular congestion resolved on the chest radiograpies on the postoperative second and third day (Fig 2-B). The patient was discharged from the hospital on the fourth postoperative day.

Fig 3.

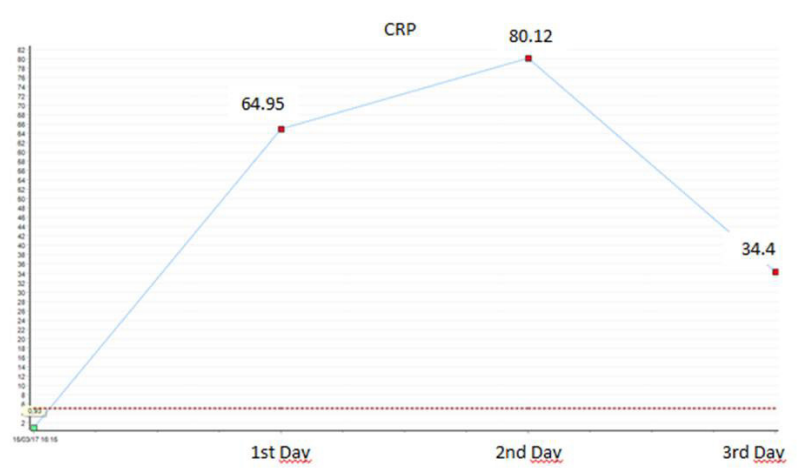

A: CRP level decreased on the postoperative $3^{\text {rd }}$ day.

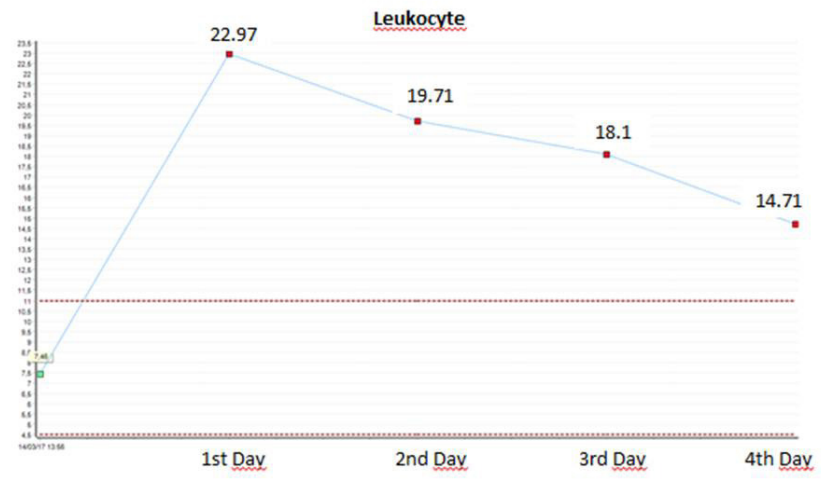

B: The diagram showing the change of leukocyte count.

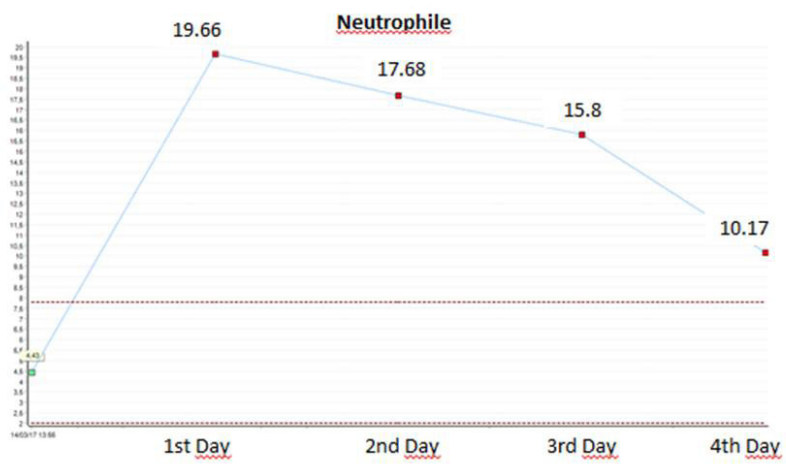

C: The diagram showing the change of neutrophil count.

\begin{tabular}{|l|l|l|}
\hline & pO2 & pCO2 \\
\hline On the 1st postoperative day & $80 \mathrm{mmHg}$ & $50.9 \mathrm{mmHg}$ \\
\hline On the 3rd postoperative day & $138 \mathrm{mmHg}$ & $45.4 \mathrm{mmHg}$ \\
\hline
\end{tabular}

Table 1: Blood gas analysis revealed that $\mathrm{pO}_{2}$ increased and $\mathrm{pCO}_{2}$ decreased on the $3^{\text {rd }}$ day postoperatively.

\section{Discussion}

A search of the reported medical data in the English language revealed 8 cases of NPPE following dental procedures and orofacial surgeries which were performed under general anesthesia [3,5-10] (Table 2). To the best of our knowledge, this article describes the fourth case of the development of NPPE following orthognathic surgery within the worldwide English literature. $[9,10]$. It was also reported that NPPE development after TMJ arthroscopy in one patient, impacted teeth extraction in one patient; impacted teeth extraction and plate removal in one patient. One of the major risk factors that lead to NPPE is known as oral surgeries, however 2 cases were reported to have pulmonary edema after dental procedures including filling and scaling [6]. Mitral valve stenosis was considered as a possible reason for ventricular failure leading to pulmonary edema in one of those patients [6] (Table 2).

Orthognathic surgeries are generally applied to young and healthy patients, however life-threatening complications such as bilateral pneumothorax, severe hemorrhage (up to $0.7 \%$ ), upper airway obstruction, and NPPE associated with these surgeries were reported in the literature [11]. Ok Hong et al reported that patients undergo mandibular setback surgery have increased risk of airway obstruction and NPPE development because of reducing the size of upper airway [9].

It is reported that upper airway obstruction can be seen especially in the prolonged maxillofacial surgeries associated with excessive mucosal edema. However, the operation time showed variability between 30 minutes and 425 minutes in the reported cases so that irritation of the larynx by oral secretions and blood during the operation and following extubation are more likely reasons for laryngospasm and NPPE development in patients who undergo oral and maxillofacial surgeries.

The chest radiograph is the most useful method for the diagnosis of pulmonary edema. Additionally, arterial blood gas analysis should be done immediately after the development of NPPE and checked out at least once a day until entire progression of the respiratory function is 
observed. Physical examination also may help evaluate the pulmonary function. Nevertheless, the differential diagnosis that includes aspiration pneumonitis, cardiogenic lung edema, and anaphylaxis should be done.

Table 2: Cases who developed NPPE following oral and maxillofacial procedures.

\begin{tabular}{|c|c|c|c|c|c|c|c|c|c|}
\hline Pt No & Investigator & Year & Age & Sex & Type of Operation & Medical History & $\begin{array}{c}\text { Duration of } \\
\text { Operation }\end{array}$ & $\begin{array}{c}\text { Blood } \\
\text { Loss }\end{array}$ & $\begin{array}{c}\text { Necessity of } \\
\text { Reintubation }\end{array}$ \\
\hline 1 & Hendler & 1993 & 32 & F & TMJ arthroscopy & $\begin{array}{c}\text { No systemic } \\
\text { diseases }\end{array}$ & 90 min & Not available & Yes \\
\hline 2 & $\begin{array}{c}\text { Yanko } \\
\text { Case 1 }\end{array}$ & 1996 & 26 & F & $\begin{array}{c}\text { Scaling } \\
\text { Filling }\end{array}$ & Autistic, deaf & 260 min & No \\
\hline 3 & $\begin{array}{c}\text { Yanko } \\
\text { Case 2 }\end{array}$ & 1996 & 16 & F & $\begin{array}{c}\text { Scaling } \\
\text { Filling }\end{array}$ & Heart murmur & 120 min & No \\
\hline 4 & Mamiya & 2009 & 27 & M & $\begin{array}{c}\text { Plate removal, } \\
\text { 3rd molar extraction }\end{array}$ & Depression & 85 min & Yes \\
\hline 5 & Waheed & 2011 & 28 & M & $\begin{array}{c}\text { Impacted molar } \\
\text { extraction }\end{array}$ & $\begin{array}{c}\text { No systemic } \\
\text { diseases }\end{array}$ & 30 min & Not available & No \\
\hline 7 & Ok Hong & 2014 & 26 & M & $\begin{array}{c}\text { Le Fort 1 } \\
\text { BSSO }\end{array}$ & $\begin{array}{c}\text { No systemic } \\
\text { diseases }\end{array}$ & 270 min & Not available \\
\hline 8 & Present case & 2018 & 27 & M & $\begin{array}{c}\text { Le Fort 1 } \\
\text { BSSO }\end{array}$ & $\begin{array}{c}\text { No systemic } \\
\text { diseases }\end{array}$ & 285 min & 890 mg & No \\
\hline
\end{tabular}

Immediate intervention to treat NPPE is crucial to avoid fatal outcomes. Invasive airway maintenance may be required depending on the severity of respiratory distress. Out of 8 patients, 4 patients, including the presented case, were required to be reintubated according to the reported data $[5,7,10]$. In our case no invasive airway maintenance was needed after 6 hours, however, noninvasive ventilation using CPAP was applied for 2 days following extubation at ICU. Therefore we can conclude that NPPE can be successfully treated by an experienced team of anesthesiologists under ICU conditions.

\section{Compliance with Ethical Standards}

Funding: Başkent University, Ankara, Turkey

Conflict of interest: The authors declare that they have no conflict of interest.

Ethical approval: Not required

Informed consent: Informed consent was obtained from the participant included in the study.

\section{References}

1. Bhattarai B, Shrestha S. Negative pressure pulmonary edema - case series and review of literature. Kathmandu Univ Med J 2011; 36(4):310-4.
2. Bhaskar B, Fraser JF. Negative pressure pulmonary edema: Pathophysiology and review of management. Saudi J Anaesth 2011;5:308-13.

3. Louis PJ, Fernandes R. Negative pressure pulmonary edema. Oral Surg Oral Med Oral Pathol Oral Radiol Endod 2002;93:4-6.

4. Garcia de Hombre AM, Cuffini A, Bonadeo A. Negative pressure pulmonary oedema after septoplasty. Acta Otorrinolaringol Esp 2013;64(4):300-302.

5. Hendler $\mathrm{BH}$, Lawrence ML. Postobstructive pulmonary edema as a sequela of temporomandibular joint arthroscopy: A case report. J Oral Maxillofac Surg 1993;51:315-17.

6. Yanko R, Garfunkel AA, Kaufman E. Pulmonary edema: A complication following dental treatment under general anesthesia. Anesth Prog 1996;43:61-3.

7. Mamiya H, Ichinohe $\mathrm{T}$, Kaneko $\mathrm{Y}$. Negative pressure pulmonary edema after oral and maxillofacial surgery. Anesth Prog 2009;56:49-52.

8. Waheed Z, Khan JA. Negative pressure pulmonary oedema: A rare complication following general anesthesia. J Pak Med Assoc 2011;61(3):290-92.

9. Ok Hong S, Chung JY, Lee DW. Quick and accurate measures in negative pressure pulmonary edema: A guideline for orthognathic surgeons. J Craniofac Surg 2014;25(5):433-35.

10. Asai K, Sonobe J, Yamashita K, Bessho K. Negative pressure pulmonary edema after orthognathic surgery for osteogenesis imperfecta. J Oral Maxillofac Surg Med Pathol 2018;30 (4):342-345.

11. Bertossi D, Vismara G, Baltieri A, Toffenetti F, Furlani M, Anesi A, et al. Bilateral pneumothorax after orthognathic surgery. Int J Oral Maxillofac Surg 2005;34 (Supp 1): 104-5. 